\title{
Influence of Public Transportation Applications for Foreign Tourists
}

\author{
G A Widoseno ${ }^{1}$, T Hidayatullah ${ }^{2}$ \\ \{ganiwidoseno@email.unikom.ac.id ${ }^{1}$, taufan.hidayatullah@email.unikom.ac.id ${ }^{2}$ \}
}

Department of Information System, Universitas Komputer Indonesia, Indonesia ${ }^{1}$, Department of Visual Communication Design, Universitas Komputer Indonesia, Indonesia $^{2}$

\begin{abstract}
The purpose of this study was to determine the effect of public transportation applications for foreign tourists. This research was conducted by discussing public transportation data and routes, tourist responses to applications, and ease of using public transportation applications. The method used in this study was descriptive, to present data in detail, depth, and actual. The results of this study showed that using public transportation applications provides more detailed knowledge related to public transportation information and how far the effect of public transportation applications for foreign tourists.
\end{abstract}

Keywords: Public Transportation, Foreign Tourists, Travel.

\section{Introduction}

Tourist destinations are places that tourists choose to include the desired services and products, especially traditional tourism destinations, which need to be accompanied by all facilities to improve the competitiveness of developing tourism, by using the latest technology infrastructure with intelligence systems, which processes information in real time, exchanges information and enhances the tourist experience. According to Rotchanakitumnuai, Technology makes it easier for tourists by using applications to determine destinations. [1]

According Yu, T. L. report, the Tada tourism industry in 2012 reached \$ 6.6 trillion to contribute to the global economy, contributing 9.3 of global GDP, and the size of the tourism industry in 2023 is estimated at $10 \%$ of global GDP [2]. According to Thomas, J. A. Based on the research results, the tourism sector accounted for 14.7 billion $(5.9 \%)$ of the New Zealand gross domestic product (GDP) [3]. According by Srivichitranond, S. Design and develop applications for tracking bus positions, to help users determine decisions [4]. According to Sandheep, S. Most of these transportation applications use similar technology using GIS (geographic information system) that uses a GPS receiver to track locations [5]. According to Tran, V. L. Explain 64\% of urban travel activities by 2050 will triple with an average time of 106 hours per year, including due to congestion and He explained to use public transportation as the main transportation to suppress private transportation [6-7]. According to Lau, J. K. S. help users plan bus trips based on information provided by other users, it is also possible to provide spatial-temporal data access as a web service [8]. According to Heryandi.R The application uses a real-time system so that the application provides information on the location of the bus from the distance the bus is currently located [9]. According to Soegoto, E. S. The 
word what we see today is the word that has experience the IT revolution that is the transformation boundaries to borderless [10].

The purpose of this study is to find out more clearly the effect of public transportation applications for foreign tourists by using web and mobile-based Trafi applications. The method used is descriptive method that presents information in detail and real time so that users can find out more clear information about this research.

\section{Material and Methods}

This research uses descriptive method, a method that can present detailed and complete data about the route of public transportation, news, name of region, means of transportation, location of the place presented by google maps. This research was conducted in Jakarta and using a Trafi application made by Trafi companies in London, this is based on mobile and web. This research was conducted in Jakarta and using a Trafi application made by a Trafi company in London, this is based on mobile and web.

\section{Results and Discussion}

From Table 1 data, the data of foreign tourists coming to Jakarta in 2017 increased from 2016, with this increase in tourists the possibility of using public transport also increased, many tourists do not want to use travel services to guide them to travel, with this application they will be facilitated to walk to a place without always asking the local people who do not necessarily know or understand what they mean. Table shows the percentage of tourists coming to Jakarta in 2017 which showed that tourists from Singapore increased by $17.70 \%$ from 2016, from Malaysia increased by $13.48 \%$ from 2016, from Australia increasing by $7.66 \%$ from 2016, from China decreasing by $6.54 \%$ from 2016, and from India increased by $4.68 \%$ from 2016.

Table 1. Percentage of international tourism came to Jakarta in 2017

\begin{tabular}{lll}
\hline Nations & Percentage & \\
\hline Singapore & 17,70 & + \\
Malaysia & 13,48 & + \\
Australia & 7,66 & + \\
Chinese & 6,54 & - \\
India & 4,68 & + \\
\hline
\end{tabular}

See This application can be opened anywhere, this application can not only be used online, but can also be used offline. to attract users this application displays a display that is easy to use, and makes it easier for users to use it. This application offers convenience in displaying routes that are passed by public transportation such as buses, public transportation, trains. And this application is connected to Google maps that can display maps directly so that users are easy to determine the location by just looking at the map listed. Or the user only enters the initial location and final location, the application will show the user what vehicle to use and the estimated time to reach the destination entered. 
This appearance includes a map that is connected to the Google map that displays all street names, place names such as recreational restaurants and others, which directly display public transportation vehicles, trains, and stops. On the left side view menu also shows the selection of the city we are currently in, the location of the determination of the starting and ending points, determining the location of the house, determining the location of the office, determining the location, and the news. This application has eight countries and if you choose the country will change language according to the country chosen (See Figure 1).



Fig 1. Main menu.

See Figure 2 By clicking on the stop we can immediately determine our departure and destination, after entering it will show the route that we will choose and what vehicle we will ride, and the estimated length of travel. 


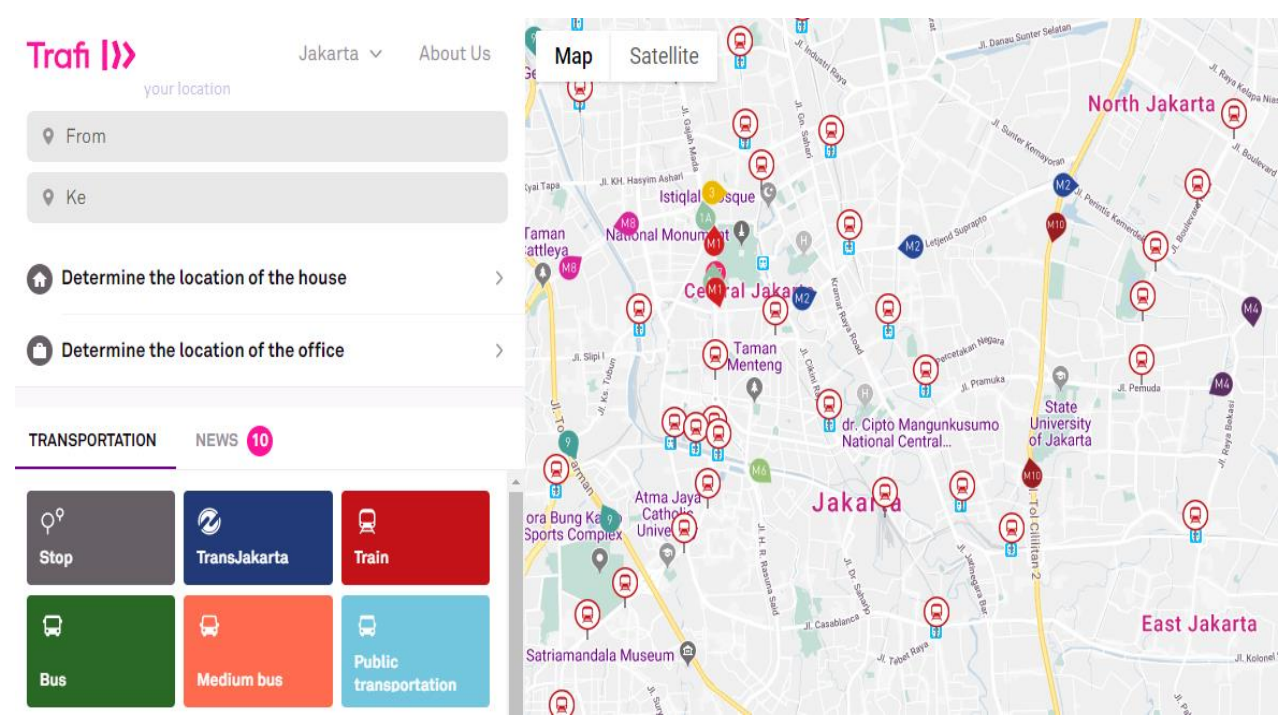

Fig 2. Locations.

See Figure 3 As shown in the picture, we can determine the city we are currently in and the map will immediately show us.

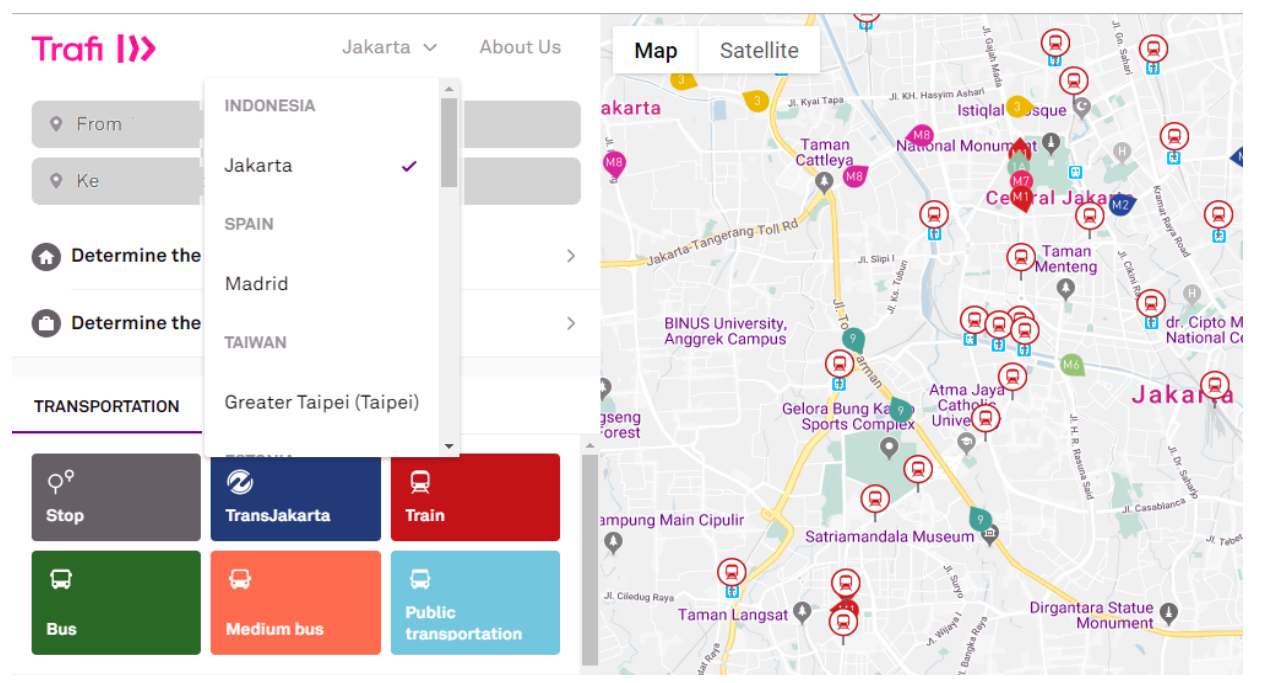

Fig 3. Place of country.

Figure 4 By clicking Trans Jakarta on the main display it will appear like a template above this, in this view we can determine which direction the bus we are going to climb, for example by clicking block M, it will display as below. 


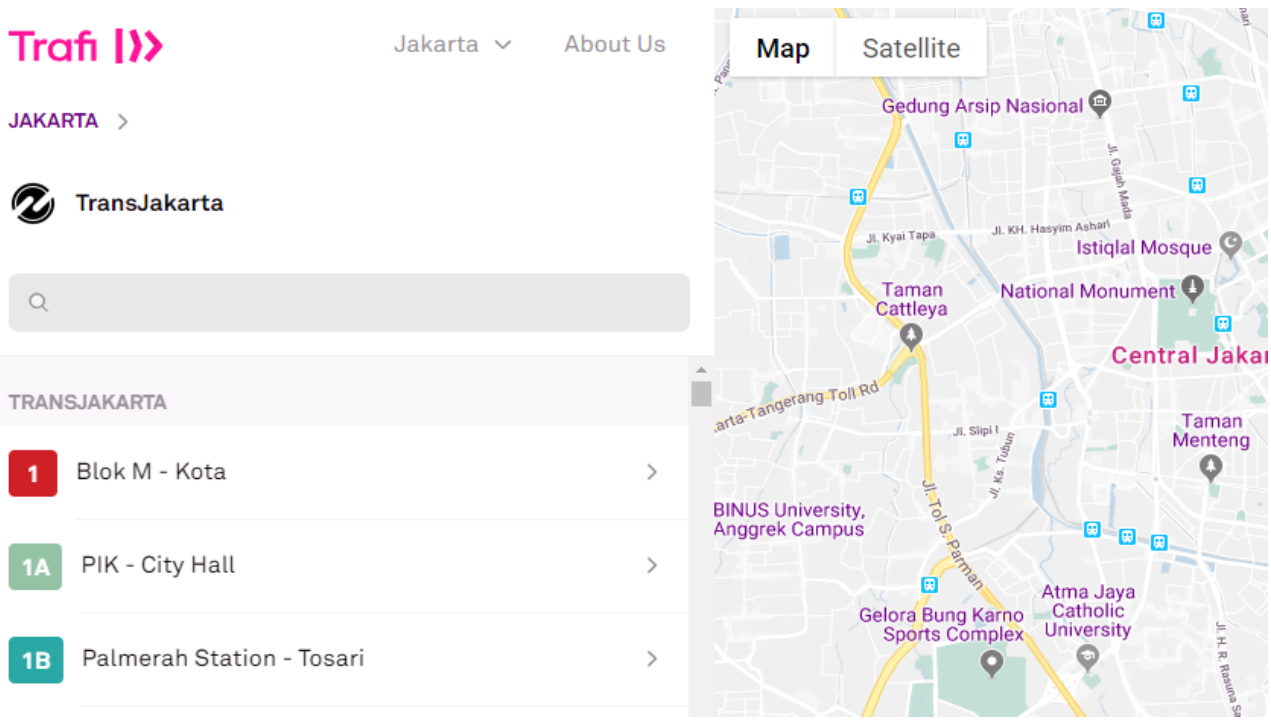

Fig 4. Trans Jakarta route.

See Figure 5 In this view it will display the route from Trans Jakarta to the M-Bintaro block via Pesanggrahan, which is immediately displayed on the map, and the explanation of which road will be passed by Trans Jakarta Bus.

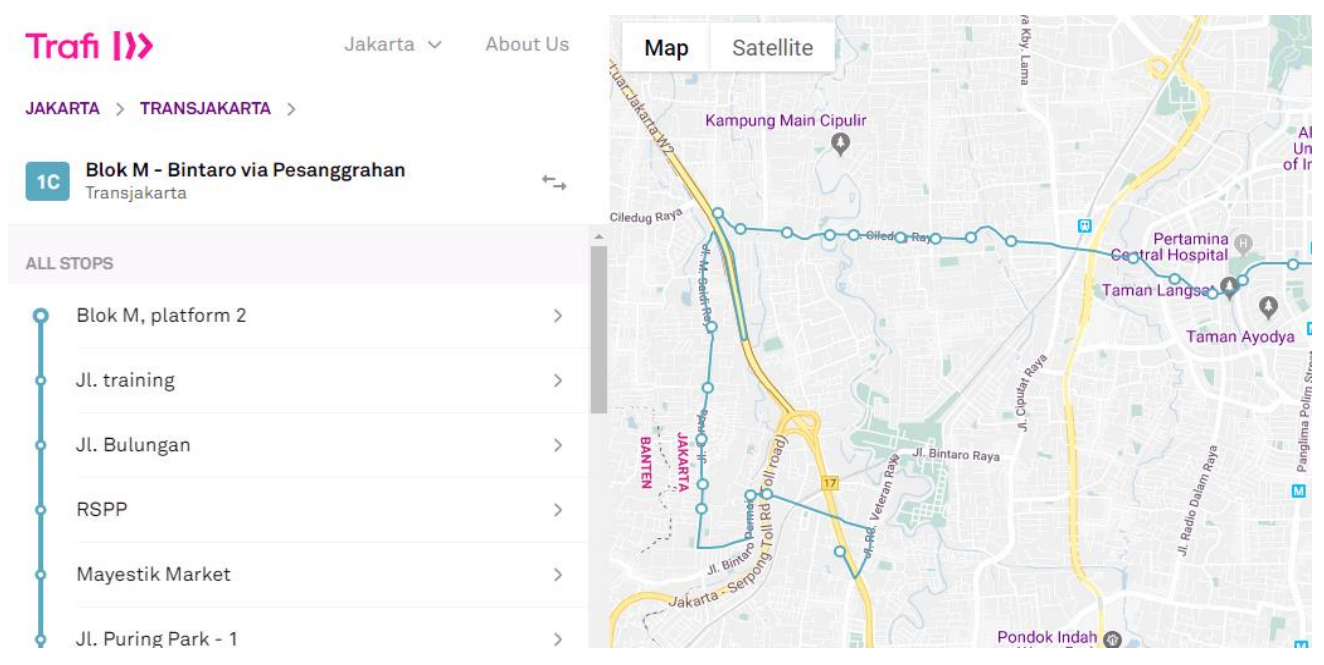

Fig 5. Route of Bus.

Figure 6 is a display if we specify the route by entering our current location to the place we are going to. Then the application will display the route option that we choose, based on the fastest time. We can choose one and on the map will show the vehicles we have to ride and where we have to stop, and ride other vehicles or on foot, as well as transportation prices. For foreign tourists, certainty about travel time is important because in general they already have planned 
visits to various destinations. Thus, the existence of these features makes it easier for application users to make decisions on the use of public transportation routes.

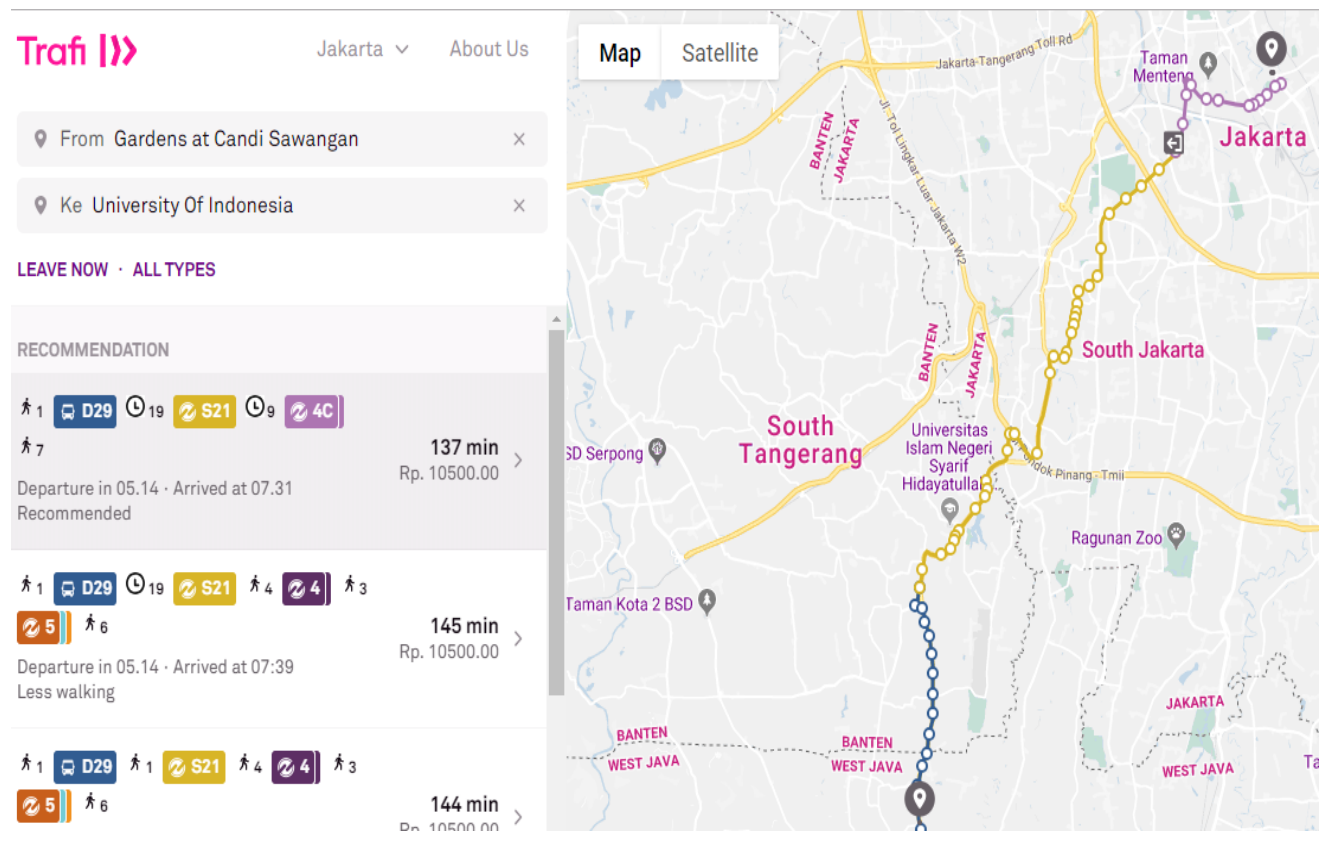

Fig 6. Train to place

\section{Conclusion}

It can be concluded that using this application can make it easier for foreign tourists. The tourists use public transportation for their trip, especially for foreign tourists who do not want to use travel services to determine their journey. Foreign tourists can more easily determine the direction of their trip and can increase the number of foreign tourists who come to the area.

\section{References}

[1] Rotchanakitumnuai, S.: Barriers to Bangkok as a Smart Destination with Internet of Things Technology. Thammasat Review, 20(2), 1-17. (2017).

[2] Yu, T. L., Wang, J. H., \& Wang, S. Y.: Exploring the expenditures of foreign tourists in taiwan on local specialty products and tea. people: International Journal of Social Sciences, 4(2). (2018).

[3] Thomas, J. A., Balanovic, J., Davison, A., O’Donnell, K., Frith, B., Fairgray, D., \& Economics, M.: Great Kiwi road trips: enhancing New Zealand's tourism industry through better visitor journeys August. (2018).

[4] Srivichitranond, S., Mannnaitham, B., Taesrikul, T., Jamnongtanachot, T., Nirapienranant, T., Charoenying, P., ... \& Kaewkiriya, T.: Design of Bus Tracking Framework Based on Android Mobile Application by Using GPS. TNI Journal of Engineering and Technology, 5(1), 15-20. (2017). 
[5] Sandheep, S., John, H., Harikumar, A., \& Panicker, J. V.: BusTimer: An android based application for generating bus schedules using crowdsourcing. In 2017 International Conference on Technological Advancements in Power and Energy (TAP Energy) (pp. 1-6). IEEE. (2017).

[6] Tran, V. L., Islam, A., Kharel, J., \& Shin, S. Y.: On the Application of Social Internet of Things with Fog Computing: A New Paradigm for Traffic Information Sharing System. In 2018 IEEE 6th International Conference on Future Internet of Things and Cloud (FiCloud) (pp. 349-354). IEEE. (2018).

[7] Tran, V. L., Islam, A., Kharel, J., \& Shin, S. Y.: On the Application of Social Internet of Things with Fog Computing: A New Paradigm for Traffic Information Sharing System. In 2018 IEEE 6th International Conference on Future Internet of Things and Cloud (FiCloud) (pp. 349-354). IEEE. (2018).

[8] Lau, J. K. S., Tham, C. K., \& Luo, T.: Participatory cyber physical system in public transport application. In Utility and Cloud Computing (UCC), 2011 Fourth IEEE International Conference on (pp. 355-360). IEEE. (2011).

[9] Heryandi, R.: Tracking Bis Trans Padang Berbasis Web (Doctoral dissertation, Politeknik Negeri Padang). (2017).

[10] Soegoto, E. S.: Entrepreneurship Menjadi Pebisnis Ulung Edisi Revisi. Elex Media Komputindo. (2014). 